\title{
Osvrti
}

https://doi.org/10.22210/suvlin.2021.092.15

\section{Ideološki i drugi vrijednosni stavovi o jeziku: odgovor Mati Kapoviću}

Mate Kapović objavio je u SL 91/2021, 103-118 »Osvrt na osvrt: o jezičnoj politici i objektivnosti « kao odgovor na moju recenziju knjige »Jeziku je svejedno « koju je napisao s Anđelom Starčevićem i Daliborkom Sarić (Zagreb 2019). Prvo moram reći da smatram neprimjerenim objavljivati odgovore na recenzije znanstvenih knjiga. Takvo što bilo bi opravdano jedino ako je recenzija zlonamjerna iliju je napisao nekvalificiran recenzent, no ne želim vjerovati da Kapović tako nešto misli o mojoj (ne osobito negativnoj) recenziji knjige »Jeziku je svejedno «. Primjerenije bi bilo da se Kapović osvrnuo na moj članak »Branič jezika standardnoga (objavljen u časopisu Jezik, 2-3/2020: 41-59), u kojem sam razradio neke od stavova i argumenata iznesenih u prikazu njegove knjige, no čini se da mu taj moj članak nije poznat. Također, neobično je što je Kapovićev odgovor na moju recenziju dugačak petnaest stranica, pa je čak tri puta dulji od nje same. U ovom ću odgovoru na Kapovićev osvrt poštedjeti čitatelje "Suvremene lingvistike« takva pristupa polemiziranju, jer bih inače morao napisati knjižicu od četrdeset i pet stranica. Zapravo, na Kapovićev osvrt (koji nije prošao znanstvenu recenziju) ne bih ni odgovarao, no budući da mi u njemu postavlja neka izravna pitanja, smatram se obaveznim odgovoriti mu na njih. Kako bih ovaj odgovor što više sažeo, osvrnut ću se samo na one Kapovićeve tvrdnjekoje proizlaze iz njegova nerazumijevanja ili netočnog prikazivanja onoga što sam u svojoj recenziji napisao.

Kapović mi (str. 104-5) imputira mišljenje po kojem je standardni jezik po svojoj gramatičkoj strukturi jasniji od nestandardnih idioma; to međutim nije ono što sam u prikazu napisao, već da jezični savjeti pomažu njihovu korisniku »da se izraze jasnije (...) i da budu razumljiviji većem krugu čitatelja ili slušatelja«. Standardni jezik, naravno, po sebi nije »jasniji« od bilo kojeg drugog idioma u smislu kako mi to imputira Kapović: trivijalna je činjenica, na koju on upozorava, da su paradigme kondicionala glagola biti u čakavskim dijalektima koji imaju oblike bim, biš, bi... itd. razlikovnije, pa u tom smislu i jasnije od paradigme istoga glagola u standardu. Međutim, izričaj na standardnim jezicima može biti jasniji od izričaja na nestandardnim idiomima u dva smisla (i samo u ta dva smisla): prvo, kada se na standardu, većinom u formalnim situacijama, govori ili piše upotrebljavajući terminologiju koja je na standardu normirana. Primjerice, u dijalektima imamo velik broj naziva za ribu brancin (lubin, dut, levrek, smudut, vuk...) i to nedvojbeno predstavlja njihovo veliko bogatstvo, ali u standardnom jeziku postoji jedan naziv za tu ribu, iu tekstu zakona o ribarenju (i drugih službenih dokumenata o ribolovstvu) očekujemo da će, radi jasnoće i nedvosmislenosti, biti korišten upravo taj naziv. ${ }^{1}$ Drugo, izričaj je na standardnom jeziku često

1 Iz iskustva mogu posvjedočiti da uporaba standardnoga nazivlja pomaže i na tržnici želiteli doista kupiti onu ribu koju ste htjeli pripremiti za ručak. 
jasniji jer je socijalno i lokalno neutralan, zajednički govorniku i njegovim slušaocima (ili čitateljima), pa se oni mogu usredotočiti na sadržaj poruke, a ne na njezinu formu. Primjerice, kada predsjednik Republike (koji bi u formalnim situacijama trebao govoriti standardnim jezikom) svojim političkim protivnicima kaže ili napiše Ćerat ćemo se, on će time svrnuti pozornost javnosti na formu/stil/registar svoje izreke i ujedno zamagliti (dakle »učiniti nejasnijim«) sadržaj, ono što je zapravo želio reći: »žestoko ćemo se verbalno sukobljavati«, »učinit ću sve u svojoj moći da u medijima umanjim vaš utjecaj«, ili nešto treće. Govoreći i pišući standardno (dakle po definiciji neutralno) nastojimo olakšati primatelju poruke da se usredotoči na sadržaj onog što želimo reći. Samo je po sebi jasno da postoji ograničen broj formalnih situacija u kojima je potrebno tako govoriti (kao i da se to ne odnosi na umjetnički izričaj).

Kapović na čak tri mjesta u svojem osvrtu traži od mene da napišem barem jedan »dobar jezični savjet«; na to je lako odgovoriti, jer dostajat će bilo koji savjet koji korisnika podsjeća na neko od nespornih pravila hrvatske gramatičke ili leksičke norme, primjerice: »U hrvatskom standardnom oblik sa prijedloga $s$ valja upotrebljavati samo ispred riječi koji počinju suglasnicima $s, \check{s}$, ž i ispred zamjenice $m n$ nm «.2 Velik je broj jezičnih savjeta u elektroničkim medijima upravo poput ovoga. Jasno je da se radi o pravilu koje su obrazovani govornici morali naučiti u školi, ali je i činjenica da su ga mnogi propustili naučiti, ili su ga nakon školovanja zaboravili. Jasno je i da ne bi dolazilo do problema u komunikaciji kada bi svi govornici hrvatskoga odjednom počeli poopćavati oblik sa u svim okolinama (kako je u srpskom standardu), no ne vidim što je sporno u tome ako se jezičnim savjetima u javnim medijima želi na pravilo o uporabi prijedloga s/sa podsjetiti one govornike hrvatskoga koji žele poštovati postojeću normu i kojima je do nje stalo. Slično je s medijskim prilozima o financijskoj pismenosti. Iako su građani Hrvatske sa srednjoškolskim obrazovanjem morali naučiti kamatni račun, mnogi do srednje dobi zaborave kako izračunati koliko će novca vratiti banci kada podignu kredit. Jasno je da sve što sadrže korisni savjeti iz financijske pismenosti stoji i u srednjoškolskim udžbenicima matematike, baš kao što se i svi korisni jezični savjeti mogu iščitati iz gramatika i rječnika standardnog jezika - međutim ljudi koji su zaboravili (ili nikad nisu naučili) srednjoškolsko gradivo nemaju vremena i volje posezati za takvim priručnicima. ${ }^{3}$ Što je loše u tome da ih o tim sadržajima u medijima infor-

2 Važno je i kako formulirati savjet da bi ga svi potencijalni korisnici razumjeli. I po tome jezično savjetništvo nije suvišno (u smislu da "sve ionako piše u standardnim gramatikama i rječnicima«), jer formulacije gramatičkih pravila u gramatikama često podrazumijevaju poznavanje određene terminologije (primjerice, u gramatici će pisati da "prijedlog $s$ dobiva navezak ispred riječi koje počinju zubnim ili nepčanim tjesnačnicima«, što osoba koja je išla u školu prije više desetljeća ne će razumjeti).

3 Jezični savjeti mogu biti korisni i onima koji bi trebali znati bolje; primjerice, kada novinar u tekstu (koji je očito prerađen iz engleskog izvornika) napiše za znanstvenicu da je »restauratorica manuskripta na kojem su zapisane legende o kralju Arturu«(Večernji list, 6. 9. 2021.), nije problem što je novinar upotrijebio anglizam latinskog podrijetla manuskript umjesto domaće riječi rukopis, nego što će neupućen čitatelj biti zbunjen jer može pomisliti da ta riječ ima neko drugo, tehničko značenje, različito od standardne riječi rukopis. Takvom bi novinaru dobro došao jezični savjet (»umjesto imenice manuskript valja upotrebljavati imenicu rukopis«) i to ne zbog purizma, nego zbog jasnoće (v. gore o smislu u kojem izričaj na standardnom jeziku može biti jasniji od nestandardnoga). Isto bi se moglo reći za Kapovićevo nepotrebno uvođenje termina »standardni dijalekt« u značenju »standardni idiom« (ili jednostavno »standard«). 
miraju kvalificirane osobe? Jasno je i da dijeljenje savjeta iz financijske pismenosti nije znanstvena djelatnost, upravo kao što i dijeljenje jezičnih savjeta o standardnoj uporabi jezika nije pisanje znanstvenih članaka. Ali ni u jednom ni u drugom nema ništa loše. Naprotiv. A djelatnost jezikoslovaca koji u medijima poučavaju ili podsjećaju građane da je na standardnom hrvatskom nepravilno govoriti »sa majkom « nije ništa ideologiziranija od djelatnosti tv-kuhara koji poučavaju da je nepravilno u talijanski risotto dodavati vrhnje (vjerovali ili ne, nekima treba takva poduka).

Polemizirajući s mojim isticanjem činjenice da autori knjige »Jeziku je svejedno « nisu pružili nikakve empirijske dokaze o tome da jezično savjetništvo čini neku društvenu štetu, Kapović ističe da bismo po analogiji trebali imati empirijske dokaze o postojanju hrvatskoga nacionalnog (pretpostavljam i jezičnog) identiteta i o tome koliko Hrvata podupire taj identitet (str. 110: »Istom bi se logikom moglo tvrditi i da se ne može govoriti o "nacionalnom identitetu«, kao što to čini prikazivač, ne dokaže li se prije toga "na objektivnom uzorkovanju« što to točno jest i postoji li to uopće u Hrvatskoj «). Savjetujem mu da pročita Ustav Republike Hrvatske (dostupan na https://www.zakon.hr/z/94/Ustav-Republike-Hrvatske ) koji u preambuli i člancima o službenom jeziku jasno o tome govori. Ustav su više nego dvotrećinskom većinom donijeli zastupnici koje su na neposrednim izborima izabrali građani ove zemlje (što predstavlja prilično vjerodostojno »uzorkovanje«).

Kapović izričito niječe postojanje vrijednosnih stavova koji nisu ideološki, pa u skladu s time ne može zamisliti ni jezičnu politiku koja ne bi bila proizvod određene ideologije (str. 107, 116). Poziva me i da navedem vrijednosne stavove o jeziku koji ne bi bili ideologizirani. Njegova je pogreška u tome što on ne razlikuje dvije vrste vrijednosnih stavova - one koji su dio ideologije, po definiciji skupa vrijednosnih stavova kojima se svjesno ili nesvjesno žele prikriti politički ili ekonomski interesi, od onih vrijednosnih stavova koji proizlaze iz ljudske naravi, koja je rezultat biološke evolucije vrste i samim time velikim dijelom genetski određena. Primjeri bi vrijednosnih stavova koji proizlaze iz ljudske naravi bili ovi: "Dobro je učinkovito komunicirati s drugima, pa je stoga svakom civiliziranom društvu potrebno sredstvo učinkovite jezične komunikacije (npr. standardni jezik)«. Taj stav proizlazi iz naše urođene kooperativnosti, bez koje kao vrsta ne bismo mogli opstati. Ili: »Dobro je kad osoba voli zajednicu u kojoj živi i djeluje, pa i onu koja nadilazi biološku obitelj«. Ovaj stav, koji se kolokvijalno naziva i domoljubljem, proizlazi iz naše urođene potrebe za stvaranjem širokih socijalnih mreža i osjećaja pripadanja kolektivnom identitetu koji nam pruža (između ostaloga) emotivnu stabilnost u zajednici. $\mathrm{S}$ druge strane, jasno je i da postoje uistinu ideološki vrijednosni stavovi: to su u osnovi proizvoljne teze koje su rezultat trenutne mode u kulturi ili skrivenih političkih interesa, primjerice: »Neke društvene skupine treba isključiti iz javne komunikacije u zajednici, npr. Židove (zato što to kaže Vođa), buržuje (jer to proizlazi iz dijalektičkih zakona historijske nužnosti), ili bijele muškarce na poziciji moći (radi ispravljanja povijesne nepravde prema svima ostalima)«; ili: »Treba odbaciti svaku tradiciju (pa i u jeziku), jer ona je uvijek sredstvo kojim vladajuća klasa održava poli- 
tički status quo u društvu i svoju dominaciju«. S onim koji ne vidi razliku između ove dvije vrste vrijednosnih stavova doista je teško raspravljati o vrijednostima.

Kapović je svjestan činjenice da, ako nije moguće imati vrijednosne stavove o jeziku koji nisu ideološki, onda se to odnosi i na njegove vlastite stavove. Kapović to priznaje, ali istovremeno tvrdi da je njegova ideologija "progresivna«. S takvim je samoopovrgavajućim stavom teško polemizirati: ako su svi vrijednosni stavovi o jeziku određeni ideologijom, ako se moja ideologija ne slaže s vašom, onda zapravo nemamo o čemu razgovarati (odakle vama pravo da tvrdite da je vaša ideologija bolja od moje?). S Kapovićevim prisvajanjem prava na znanje o tome što je "progresivno " nikad se ne ću složiti: malo skromnosti i skepse dobro dođe svakom znanstveniku. Pa ipak, istaknuo bih da je teret dokaza na Kapoviću i njegovim istomišljenicima upravo zbog radikalnosti njihove hipoteze.

Alternativna je hipoteza upravo ona prema kojoj neki vrijednosni stavovi o jeziku i drugim elementima društva i kulture (poput npr. nacionalnog identiteta) proizlaze iz ljudske naravi, koja je, pak, u najvećoj rezultat je biološke evolucije vrste. To, da želimo pripadati široj zajednici izvan uže obitelji i da želimo imati komunikacijski sustav koji pripada toj zajednici (»svoj jezik«) antropološka je konstanta potvrđena u najrazličitijim kulturnim zajednicama: imamo razloga vjerovati da ona nije rezultat nametnute ideologije koja odražava trenutne odnose moći u društvu. Ovo, međutim, nije mjesto na kojem namjeravam govoriti o sociobiološkim osnovama vrijednosnih stavova (uključujući i stavove o jeziku) - o tome sam pisao u knjizi »Jezična raznolikost svijeta«(Zagreb 2005), a neupućenima kao polazište za takvo gledanje na jezik, kulturu i društvo preporučujem popularno i jasno pisanu knjigu Stevena Pinkera »The Blank Slate. The Modern Denial of Human Nature« (London 2002).

Naposljetku, svakomu tko misli da su ispravni samo »progresivni« vrijednosni stavovi koji pozivaju na promjene odnosa u društvu bit će teško odgovoriti na jednostavno pitanje: zašto? Kapovićevo aktivističko pozivanje na Marxovu maksimu o svijetu koji ne treba tumačiti, već mijenjati (str. 111) ne pomaže njegovoj argumentaciji (pozivanje na autoritete obično je kontraproduktivno). Iskustvo nam pokazuje koliko je pogrešno vjerovati da je svaka promjena u društvu, jeziku i kulturi - a priori dobra. Povijest dvadesetog stoljeća poučava nas da su oni koji su slijedili spomenutu Marxovu maksimu učinili mnogo više zla nego koristi. Kao društveni eksperiment, marksistička ideologija zasluženo je otišla u ropotarnicu povijesti koncem prošloga stoljeća; međutim, kulturni marksizam, koji niječe postojanje ljudske naravi i sve vrijednosti shvaća kao ideologije zasnovane na odnosima moći u društvu, živi i dalje u glavama mnogih, pa i inače inteligentnih ljudi. Završavajući ovu polemiku sa svoje strane mogu samo reći da mi je žao što je tako.

Ranko Matasović 